\title{
Permainan tradisional Kancing Gumi dalam tinjauan pendidikan karakter (Studi kualitatif pada siswa SDN 1 Buahan, Tabanan Bali)
}

\author{
Ni Putu Eni Astuti $\bowtie$, STKIP Suar Bangli Bali \\ $\bowtie$ putu.eniastuti@gmail.com
}

\begin{abstract}
This study was intended to describe the traditional game activities of Kancing Gumi in character education review. This research is a qualitative descriptive study involving research at SDN 1 Buahan Tabanan, Bali. Data collection is collected through interviews and observations. Data analysis used content analysis of the Kancing Gumi's game procedure and also the data obtained from interviews and observations of children. Validation of data is done by expert discussion. The results showed that the traditional game of Kancing Gumi could sharpen three character components namely moral knowledge, moral attitude, and moral behavior. Among those three components, the game of Kancing Gumi contains a very high component of moral attitude including (a) conscience, (b) self-esteem, (c) empathy, (d) love of kindness, (e) self-control and (f) humility. The development of this moral attitude breeds character values including: the values of sportsmanship, togetherness, cooperation, empathy, self-control.
\end{abstract}

Keywords: Traditional Games, Kancing Gumi, Character Education

Abstrak: Tulisan ini bertujuan untuk menggambarkan kegiatan permainan tradisional kancing gumi dalam tinjauan pendidikan karakter. Penelitian ini merupakan penelitian deskriptif kualitatif yang melibatkan anak-anak di SDN 1 Buahan Tabanan, Bali. Pengumpulan data dilakukan melalui wawancara dan observasi. Analisis data menggunakan analisis isi terhadap prosedur permainan kancing gumi ditambah data hasil wawancara dan observasi terhadap anak. Validasi terhadap data dilakukan dengan diskusi ahli. Hasil penelitian menunjukkan bahwa permainan tradisional kancing gumi dapat mengasah tiga komponen karakter yakni pengetahuan moral, sikap moral, dan perilaku moral. Dari ketiga komponen tersebut, permainan kancing gumi mengandung komponen sikap moral yang sangat tinggi diantaranya (a) nurani, (b) harga diri, (c) empati, (d) cinta kebaikan, (e) kontrol diri dan (f) rendah hati. Pengembangan sikap moral ini melahirkan nilai-nilai karakter diantaranya adalah: nilai sportivitas, kebersamaan, kerjasama, empati, pengendalian diri.

Kata Kunci: Permainan Tradisional, Kancing Gumi, Pendidikan Karakter

Received 13 March 2020; Accepted 14 April 2020; Published 01 June 2020

Citation: Astuti, N. P. E. (2020). Permainan tradisional Kancing Gumi dalam tinjauan pendidikan karakter (Studi kualitatif pada siswa SDN 1 Buahan, Tabanan Bali). Premiere Educandum : Jurnal Pendidikan Dasar dan Pembelajaran, 10(1), 63 - 71. Doi.org/ 10.25273/pe.v10i1.6162 


\section{PENDAHULUAN}

Dunia anak identik dengan kegiatan bermain. Secara alamiah, karakteristik anak adalah senang bermain, senang bergerak, senang bekerja dalam kelompok, dan senang merasakan, melakukan, atau memperagakan sesuatu secara langsung. Keempat karakteristik itu terakomodasi didalam kegiatan bermain. Bermain didefinisikan sebagai kegiatan yang menyenangkan namun memberikan manfaat yang besar bagi perkembangan anak (Hurlock, 1933;Papalia, Old, \& Fieldman, 2000). Dalam dunia anak, bermain merupakan kontributor kunci terhadap berbagai aspek perkembangan baik kognitif, emosional, kepribadian, maupun sosial. Namun, menurut Schaefer \& Reid dalam (Iswinari, 2019) istilah bermain atau play dibedakan dengan istilah permainan atau games. Bermain merupakan aktivitas yang terjadi secara ilmiah dan ditemukan baik pada manusia maupun binatang, sedangkan permainan merupakan merupakan salah satu bentuk bermain yang lebih berorientasi pada tujuan, memiliki prosedur, dan bersifat lebih serius.

Kemajuan teknologi yang semakin pesat ternyata juga mempengaruhi aktivitas bermain anak. Saat ini, anak-anak lebih sering bermain permainan digital seperti video games, playstation, dan games online. Permainan ini memiliki kesan sebagai permainan modern karena dimainkan menggunakan peralatan yang canggih dengan teknologi yang mutakhir. Permainan ini biasanya dilakukan di dalam ruangan dan lebih bersifat individual. Permainan-permainan tersebut tidak mengembangkan keterampilan sosial anak. Anak bisa pandai dan cerdas namun secara sosial kurang terasah (Seriati dan Nur, 2012). Sejalan dengan itu, sebagai contoh dalam permainan engklek yang dimainkan secara digital dengan komputer diperoleh kenyataan bahwa nilai-nilai pendidikan yang terkandung sebelumnya menjadi hilang (Tzeng \& Huang, 2010).

Permainan tradisional merupakan permainan yang telah diturunkan dari satu generasi ke generasi berikutnya yang mengandung nilai baik, positif, bernilai, dan diinginkan (Bishop \& Curtis, 2001). Dengan demikian, di dalam permainan tradisional terdapat nilai-nilai luhur untuk dapat diwariskan kepada anak-anak sebagai generasi penerus. Sejalan dengan itu permainan anak tradisional merupakan permainan yang memberikan manfaat untuk perkembangan anak (Iswinarti, 2005) dan merupakan kekayaan budaya bangsa (Sedyawati, 1999). Permainan tradisional juga merupakan permainan yang mengandung nilai-nilai budaya yang dapat menjadi pemberi identitas bagi sebuah budaya lokal sehingga dapat menjadi local wisdom bagi sebuah budaya (Dharmamulya, 2008).

Salah satu permainan anak tradisional yang masih lestari di Desa Buahan Tabanan, Bali adalah permainan yang bernama Kancing Gumi. Berdasarkan observasi dan studi pustaka, nama permainan ini belum ada atau dimainkan sebelumnya, namun memiliki kemiripan dengan permainan dhingklik oglak aglik di Jawa Tengah atau prepet jengkol di Jawa Barat. Permainan ini dipopulerkan oleh salah seorang pemerhati anak sekaligus seniman dari desa Buahan, I Wayan Merta. Permainan ini biasanya dimainkan oleh anak-anak perempuan, namun dapat juga dimainkan oleh anak laki-laki. Permainan ini kerap dipraktekkan dalam kegiatan-kegiatan anak di desa tersebut dan sangat diminati oleh anak-anak. Permainan kancing gumi ini juga dimainkan oleh anak-anak pada kegiatan Bulan Bahasa Bali yang dilaksanakan serempak di seluruh desa adat di Bali pada bulan Februari 2019.

Secara alamiah permainan tradisional mampu menstimulasi berbagai aspek-aspek perkembangan anak yaitu: motorik, kognitif, emosi, bahasa, sosial, spiritual, ekologis, dan nilainilai/moral (Misbach, 2006). Permainan anak tradisional mempunyai hubungan yang erat dengan perkembangan intelektual, sosial, emosi, dan kepribadian (Iswinarti, 2005). Berbagai aspek perkembangan yang terstimulisasi dari kegiatan permainan tradisional ini bermuara pada pembentukan karakter anak. Menurut Lickona (Zubaedi, 2004), pendidikan karakter yang benar harus melibatkan tiga komponen pendidikan karakter diantaranya adalah (1) aspek knowing the good (moral knowing), (2) desiring the good atau loving the good (moral feeling), dan (3) acting the good (moral action). Ketiga aspek ini memiliki subkomponen yang lebih spesifik terhadap pembentukan karakter seorang anak. Untuk itu, fokus pada penelitian ini 
yaitu (1) mengkaji aspek moral knowing, (2) aspek moral feeling, dan (3) aspek moral action yang terkadung dalam permainan anak tradisional kancing gumi.

\section{METODE}

Penelitian ini merupakan penelitian deskriptif kualitatif. Penelitian deskriptif kualitatif ini merupakan pendekatan ilmiah dan mengandalkan manusia sebagai instrumen penelitian (Creswell, 2015). Data yang terkumpul berbentuk narasi, kata-kata, dan gambar di rangkai menjadi sebuah kesimpulan yang berbentuk deskripsi.

Dalam penelitian ini yang menjadi subjek penelitian adalah anak usia sekolah dasar yang duduk di kelas 4, 5, dan 6 SDN 1 Buahan Tabanan, Bali. Jika ditinjau dari usia maka anak kelas 3, 4, 5sekolah dasar kebanyakan berada pada masa anak-anak akhir usia yang termasuk kategori masa anak-anak akhir adalah 8-11 tahun (Santrock, 2000).

Metode pengumpulan data yang digunakan dalam penelitian ini adalah observasi, wawancara, dan diskusi ahli. Observasi dan wawancara digunakan untk mengetahui prosedur permainan kancing gumi. Diskusi ahli digunakan untuk mengumpulkan data dalam rangka memperoleh aspek-aspek pendidikan karakter baik aspek moral knowing, (2) aspek moral feeling, dan (3) aspek moral action yang terkadung dalam permainan anak tradisional kancing gumi.

Analisis data dilakukan secara kualitatif yaitu melakukan analisis isi terhadap prosedur permainan kancing gumi yang dilengkapi dengan observasi dan wawancara terhadap anak yang melakukan permainan tersebut, sehingga diperoleh gambaran tentang pendidikan karakter yang terkandung didalamnya. Gambaran hasil analisis isi kemudian didiskusi dengan ahli yakni pencipa permainan kancing gumi dan dosen yang fokus penelitiannya tentang pendidikan karakter.

\section{HASIL PENELITIAN}

Permainan kancing gumi sekilas serupa dengan permainan prepet jengkol atau permainan dingklik oglak-aglik yang sering dimainkan oleh anak-anak di daerah Jawa. Pembeda yang paling jelas adalah lagu yang dinyanyikan selama permainan berlangsung. Permainan kancing gumi tentu menggunakan lagu dengan Bahasa Bali, yakni:

\section{Nengkleng enjok enjok ane nengkleng batis perot Nengkleng enjok enjok ane nengkleng batis perot Kedeng kangin kedeng kauh ane kalah ulung maglebug}

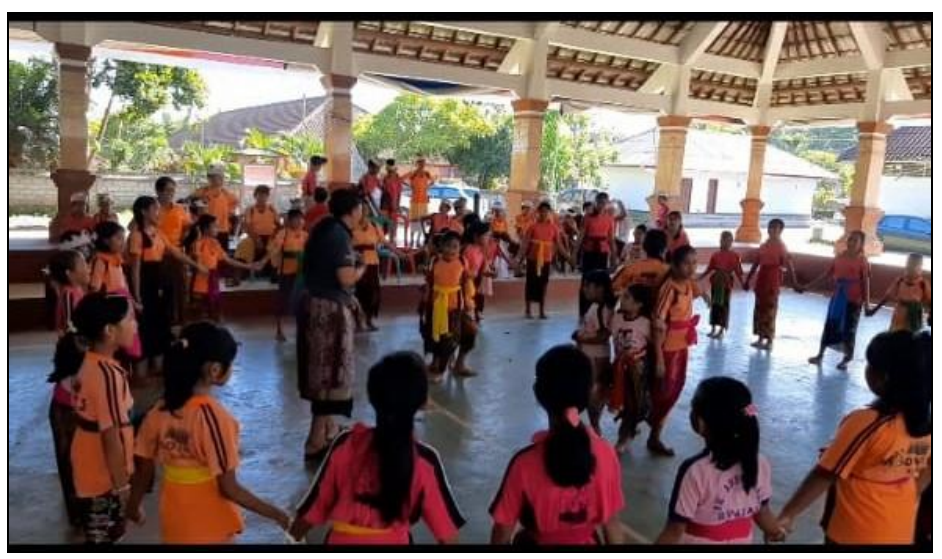

GAMBAR 1. Permainan kancing gumi

Permainan ini sangat cocok dilakukan oleh anak-anak dalam jumlah yang besar dan bersifat kompetisi. Untuk menyeimbangkan kekuatan fisik dan memperhatikan kenyamanan 
dalam bermain, maka permainan ini dipisahkan antara kelompok anak perempuan dan anak laki-laki. Selama permainan berlangsung, terdapat satu orang yang bertugas sebagai pemandu sekaligus wasit diluar anggota permainan. Permainan ini sebagaimana nampak pada Gambar 1.

\section{Prosedur Dan Cara Bermain}

Secara ringkas, prosedur dan cara bermain permainan kancing gumi nampak dalam Gambar 2 berikut.

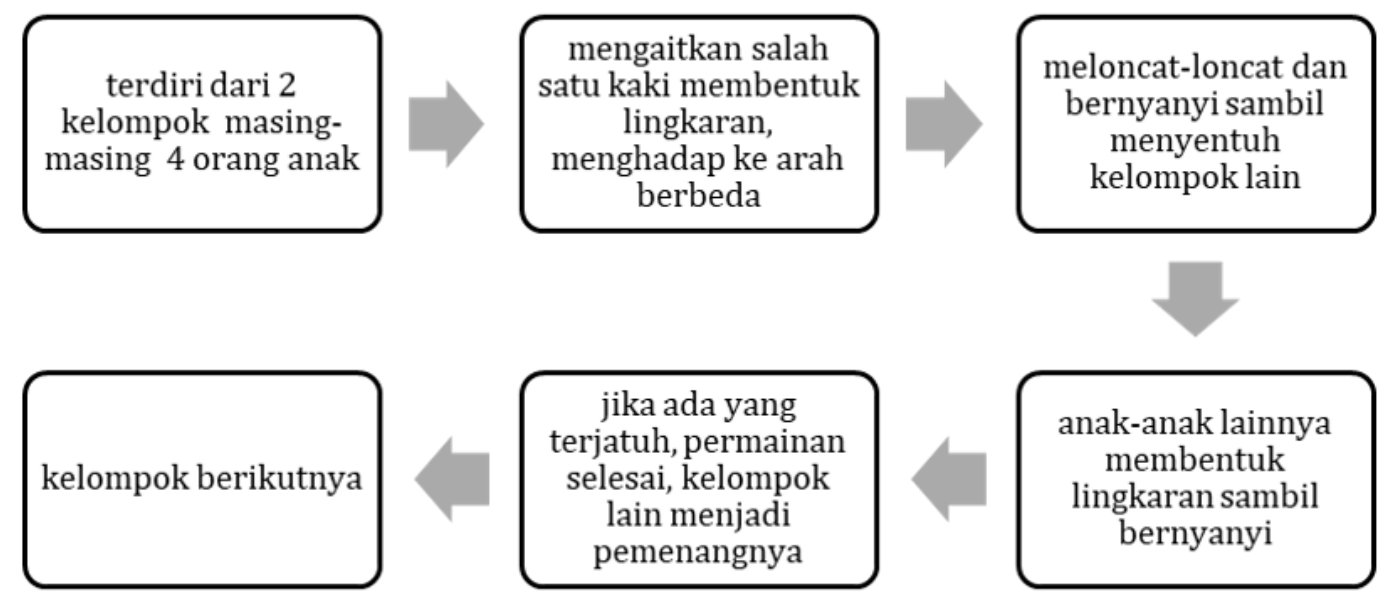

GAMBAR 2. Prosedur dan cara bermain permainan kancing gumi

Dalam satu kali permainan yang boleh bermainan hanya 2 kelompok. Jika terdapat lebih dari dua kelompok, maka permainan akan dilakukan secara bergiliran. Setiap anak yang bermain di dalam kelompoknya harus mengaitkan salah satu kaki, dengan posisi tangan saling bergandengan, badan mengarah kearah yang berbeda, lalu meloncat-loncat sembari menyentuh kelompok lawan. Saat permainan dimulai, peserta lain menyanyikan lagu permainan kancing gumi. Jika terdapat kelompok yang pesertanya terjatuh, maka permainan akan dianggap selesai dan kelompok lainnya yang menjadi pemenangnya. Permainan dilanjutkan ke kelompok berikutnya, sampai terpilih satu kelompok yang paling bertahan, itulah juaranya.

\section{Pendidikan Karakter}

Proses pembentukan karakter pada manusia dapat dilihat berdasarkan pendekatan teori psikologi behavioristik, kognitif, dan social learning (meliputi proses mengetahui, memikirkan, melakukan, dan membiasakan) (Eni, Astuti, 2015). Pendekatan behavioristik menekankan mengenai respon perilaku yang dapat diamati dan merupakan penentu lingkungannya. Pendekatan kognitif menekankan pada proses-proses mental yang terlibat dalam mengetahui bagaimana kita mengarahkan perhatian, mempersiapkan, mengingat, berpikir, dan memecahkan masalah. Pendekatan teori belajar sosial lebih ditekankan pada perlunya conditioning (pembiasaan merespon) dan imitation (peniruan). Dari pendekatan beberapa teori di atas, jelas terlihat behwa sebenarnya setiap pendekatan tidak dapat berdiri sendiri. Dalam pembentukan perilaku individu, ia berproses melalui mengetahui tentang suatu perilaku atau tindakan, yang kemudian difikirkan, dan dilakukan sehingga menjadi sebuah kebiasaan. Jika perilaku yang menjadi kebiasaan ini bersifat positif, maka akan terbentuk karakter yang baik dalam diri individu tersebut, begitu juga sebaliknya.

Pembentukan karakter melibatkan lima tahap diantaranya adalah (1) Adanya nilai yang diserap seseorang dari berbagai sumber, kemudian (2) nilai tersebut membentuk pola fikir seseorang yang secara keseluruhan keluar dalam bentuk rumusan visi, (3) visi turun ke wilayah 
hati membentuk suasana jiwa yang secara keseluruhan membentuk mentalitas, dan kemudian (4) mentalitas mengalir memasuki wilayah fisik dan melahirkan tindakan yang secara keseluruhan disebut sikap. Sikap-sikap dominan dalam diri seseorang yang secara keseluruhan mencitrai dirinya adalah apa yang disebut sebagai karakter atau kepribadian. Kualitas dari setiap karakter didalam diri seseorang tercermin kedalam komponen-komponen karakter menurut Lickona ((Zubaedi, 2004) terdiri atas (1) Moral Knowing (Pengetahuan Moral), (2) Moral Feeling (Perasaan Moral), dan (3) Moral Acting (Tindakan Moral).

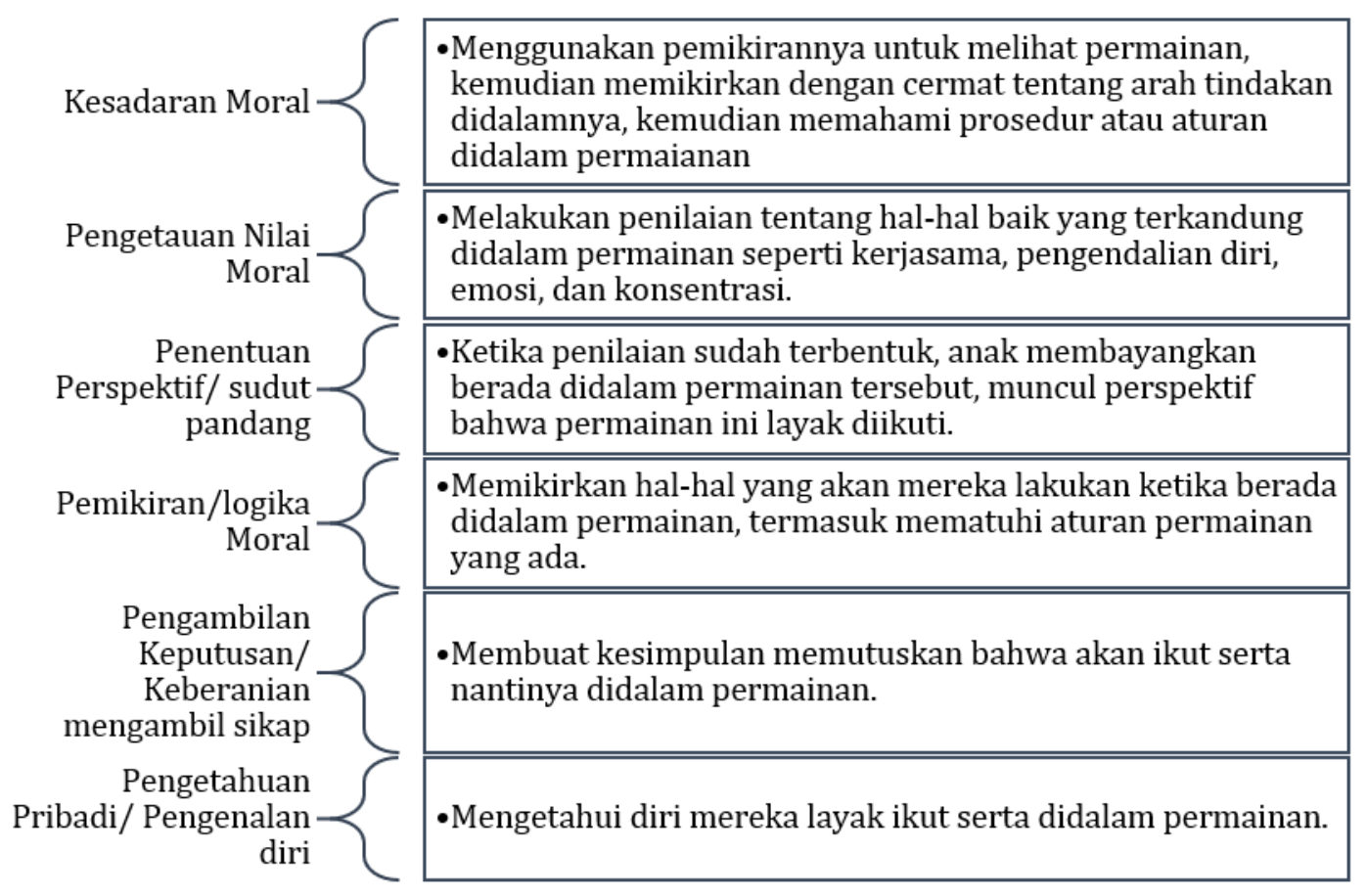

Gambar 3. Pengetahuan moral permainan kancing gumi

Hati Nurani/
diri

GAMBAR 4. Perasaan moral permainan kancing gumi 


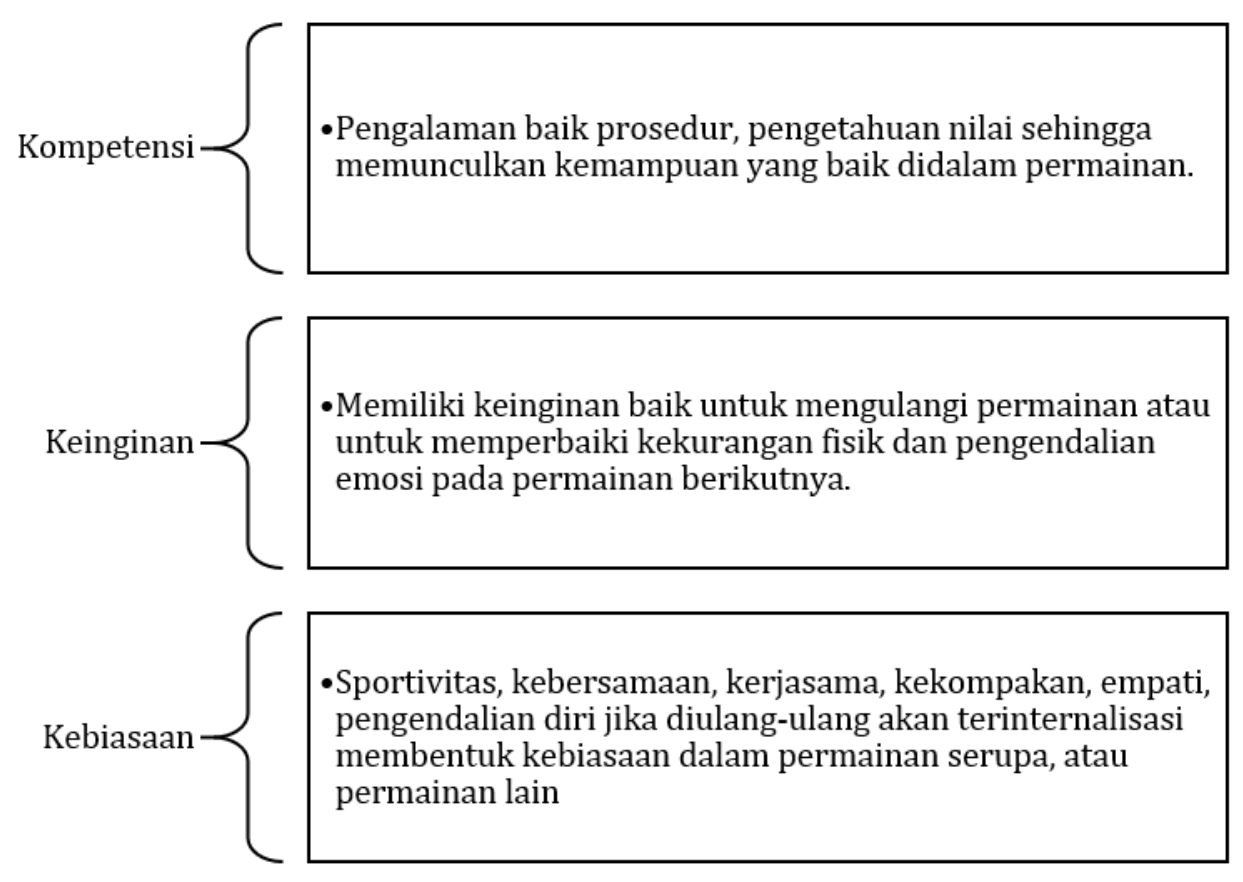

GAMBAR 5. Tindakan moral permainan kancing gumi

\section{Moral Knowing (Pengetahuan Moral)}

Moral knowing adalah komponen yang berada pada ranah kognitif individu. Komponen ini berada pada tahapan awal pembentukan karakter. Seseorang yang memiliki karakter yang baik, akan memiliki ruang yang luas didalam kognisinya untuk memasukkan dan mengolah data atau fakta yang diperoleh dari inderanya. Jadi, karakter yang baik dimulai dari penerimaan dan persepsi yang baik dari apa yang diterimanya. Di dalam permainan kancing gumi, anak-anak melalui tahap ini sebelum dan atau juga selama permainan bahkan sesudah permainan berlangsung didalam kognisi mereka sebagaimana yang nampak pada Gambar 3.

\section{Moral Feeling (Perasaan Moral)}

Komponen karakter ini merupakan komponen lanjutan yang menyentuh aspek afeksi anak. Dalam permainan ini komponen perasaan moral adalah aspek yang dominan terasah. Nilai-nilai karakter berupa sportivitas, kebersamaan, kerjasama, kekompakan, empati, pengendalian diri, merupakan nilai yang dapat berkembang dalam diri anak terlebih saat permainan ini arahkan oleh guru atau pemandu permainan yang sudah dewasa. Didalam penelitian ini, pencipta permainan ini juga terlibat didalam permainan sebagai pemandu yang berugas untuk mengatur, mengarahkan, dan menyemangati permainan. Pemandu juga memotivasi kelompok yang kalah agar tidak berkecil hati karena ada sesi lain sehingga dapat ikut bermain lagi. Komponen perasaan moral yang muncul dan terasah dalam permainan kancing gumi nampak sebagaimana dalam Gambar 4.

\section{Moral Acting (Tindakan Moral)}

Komponen tindakan ini merupakan hasil dari perpaduan kedua komponen karakter lainnya. Kompetensi didalam permainan baik prosedur dan pengetahuan nilai yang melibatkan aspek kognisi memunculkan kemampuan yang baik pada anak. Aspek keinginan memunculkan rasa untuk mengulangi permainan, memperbaiki kekurangan fisik, ataupun pengendalian emosi pada permainan berikutnya. Terakhir, jika nilai-nilai sportivitas, kebersamaan, kerjasama, kekompakan, empati, pengendalian diri dilakukan secara berulang-ulang akan 
terinternalisasi didalam karakter anak sehingga membentuk kebiasaan baik dalam permainan serupa atau permainan lainnya, sebagaimana nampak pada Gambar 5.

\section{DISKUSI}

Permainan adalah situasi bermain yang terkait dengan beberapa aturan atau tujuan tertentu, yang menghasilkan kegiatan dalam bentuk tindakan bertujuan (Misbach, 2006). Dengan demikian, dapat dipahami bahwa dalam bermain terdapat aktivitas yang diikat dengan aturan untuk mencapai tujuan tertentu. Hal ini sejalan dengan Montessori yang mengatakan bahwa bermain adalah cara anak bekerja (Morrison, George S., 2016). Jadi, ketika kegiatan yang dilihat oleh orang dewasa sebagai kegiatan bermain sesungguhnya adalah sebuah kegiatan"bekerja" dalam diri anak. Dengan demikian, terdapat perbedaan makna dari sebuah permainan jika dilihat dari sudut pandang anak itu sendiri dan dari kacamata orang dewasa. Tidak jarang orang dewasa hanya memandang kegiatan bermain hanyalah sebagai sebuah kegiatan mengisi waktu atau untuk bersenang-senang saja. Namun ternyata, jauh daripada itu seperti yang diungkapkan oleh Rogers \& Sawyer's dalam (Iswinarti, 2010) mengemukakan bahwa hingga pada anak usia sekolah, bermain bagi anak memiliki arti yang sangat penting. Adapun nilai-nilai penting dalam bermain bagi anak, yaitu (1) meningkatkan kemampuan problem solving pada anak, (2) menstimulasi perkembangan bahasa dan kemampuan verbal, (3) mengembangkan keterampilan sosial, dan (4) merupakan wadah pengekspresian emosi. Hal ini tidak terlepas dari aturan dan interaksi yang berlaku didalam sebuah permainan.

Interaksi merangsang tumbuhnya berbagai macam nilai dalam diri anak. Seperti dalam hasil penelitian yang dilakukan oleh Eka Nugrahastuti (2016) yang termuat dalam Prosiding Seminar Nasional Inovasi Pendidikan yang meneliti tentang nilai-nilai karakter pada permainan tradisional. Penelitian ini mendapati bahwa bahwa terdapat nilai-nilai karakter pada permainan tradisional gobag sodor, cublak-cublak suweng, dan engklek. Nilai-nilai yang terkandung dalam permainan tradisional gobag sodor dapat antara lain adalah nilai kejujuran, nilai sportivitas, nilai kerjasama, nilai pengaturan strategi dan nilai kepemimpinan. Nilai-nilai yang terkandung pada permainan tradisional cublak-cublak suweng adalah nilai kerjasama, nilai kerukunan, dan nilai kreatifitas. Nilai-nilai yang terkandung dalam permainan engklek yaitu melatih kedisplinan, ketangkasan, bersosialisi dan kesehatan.

Penelitian sejenis dilakukan oleh Iswinarti yang termuat didalam Seminar Nasional dan Gelar Produk tahun 2016. Penelitian ini mendapati bahwa terdapat nilai-nilai problem solving pada permainan tradisional engklek mencakup aspek-aspek mencari dan memahami masalah, menyusun strategi pemecahan masalah yang baik, dan mengeksplorasi solusi.

Dari beberapa hasil penelitian diatas didapat sebuah kesamaan bahwa permainan tradisional sarat dengan nilai. Nilai-nilai yang terkandung didalamnya adalah nilai karakter pada aspek kognitif, sosial, emosi dan identitas, serta menonjolkan nilai-nilai karakter sosial (Batusangkar, 2017) dalam jurnal Bimbingan dan Konseling. Nilai-nilai merupakan sebuah kesatuan dari kebaikan didalam kehidupan bermasyarakat. Masyarakat didalam konteks kehidupan anak dapat berupa keluarga, saudara, dan didalamnya juga terdapat teman-teman didalam kelompok bermainnya. Maka dari itu, permainan menjadi jembatan yang menghubungkan antara nilai-nilai kebaikan dan diri anak sendiri. Pembinaan karakter juga sangat diperlukan seiring dengan usia dan pergaulan dalam lingkungan anak.

Lebih jauh, (Cahyono, 2012) mengemukakan sejumlah karakter yang dimiliki oleh permainan tradisional yang dapat membentuk karakter positif pada anak diantaranya: (1) permainan tradisional cenderung menggunakan atau memanfaatkan alat atau fasilitas di lingkungan sekitar tanpa harus membelinya sehingga perlu daya imajinasi dan kreativitas yang tinggi (2) permainan anak tradisional melibatkan pemain yang relatif banyak. Hal ini bertujuan untuk mendahulukan faktor kesenangan bersama dan bermaksud memperdalam kemampuan interaksi antarpemain (potensi interpersonal), dan (3) permainan tradisional menilik nilai-nilai luhur dan pesan-pesan moral tertentu seperti nilai-nilai kebersamaan, kejujuran, tanggung jawab, sikap lapang dada (kalau kalah), dorongan berprestasi, dan taat pada aturan. Semua itu 
didapatkan jika anak-anak yang bermain benar-benar menghayati, menikmati, dan mengerti intisari dari permainan tersebut. Nilai-nilai ini akan tumbuh dalam diri anak. Jika karakterkarakter ini telah tertanam dan berkembang kuat dalam diri anak, maka mereka akan tumbuh menjadi generasi yang bernilai. Hal ini sangat relevan dan menjadi urgensi di era globalisasi/digital saat ini. Pendidikan Karakter sangat penting sebagai usaha membentuk karakter generasi bangsa yang bukan hanya terampil dan cerdas, namun juga berakhlak mulia. Meski menghadapi berbagai problematika dalam proses pelaksanaanya, tapi dengan kerjasama berbagai pihak, harapan pembentukan insan Indonesia yang cerdas dan berkarakter sesuai Pancasila dan nilai-nilai agama dapat terealisasi (Primasari, 2019).

\section{SIMPULAN}

Permainan tradisional kancing gumi merupakan salah satu permainan tradisional di Desa Buahan Tabanan, bali yang diciptakan oleh seniman dan tokoh setempat, I Wayan Merta. Permainan ini dimainkan oleh 2 kelompok yang masing-masing terdiri dari 4 orang anak. Setiap anak yang bermain di dalam kelompoknya harus mengaitkan salah satu kaki, dengan posisi tangan saling bergandengan dan diiringi lagu permainan sambil meloncat-loncat sembari menyentuh kelompok lawan. Jika terdapat kelompok yang pesertanya terjatuh, maka permainan akan dianggap selesai dan kelompok lainnya yang menjadi pemenangnya. Permainan ini dapat mengasah tiga komponen karakter yakni pengetahuan moral, sikap moral, dan perilaku moral. Komponen sikap moral yang sangat tinggi meliputi nurani, harga diri, empati, cinta kebaikan, kontrol diri, dan rendah hati melahirkan nilai-nilai karakter yakni nilai sportivitas, kebersamaan, kerjasama, empati, dan pengendalian diri. Nilai-nilai ini sangat penting didalam kehidupan anak dalam masa tumbuhkembangnya, baik untuk perkembangannya secara individu, maupun didalam lingkungan sosialnya. Permainan ini merupakan salah satu media penanaman nilai dan penumbuhan karakter, oleh karena itu perlu adanya sosialisasi dan pelestarian permainan ini secara berkelanjutan.

\section{DAFTAR PUSTAKA}

1. Astuti, E. (2016). Modul Psikologi Pendidikan. Denpasar. CV Wiyata Bhakti

2. Batusangkar, IAIN. (2017). Nilai-Nilai Karakter pada Anak Dalam Permainan Tradisionan dan Moderen. Jurnal Bimbingan dan Konseling. 04 (2); 2017; 89-96

3. Bishop, J. C., \& Curtis, M. (2001). Play Today In The Primary School Playground: Life, Learning, And Creativity. Buchingham: Open University Press

4. Cahyono, N. (2011). "Transformasi Permainan Anak Indonesia”. Artikel. http://permatanusantara.blogspot.com. Diakses pada tanggal 10 April 2020.

5. Creswell, J. W. (2015). Penelitian Kualitatif \& Desain Riset. Yogyakarta: Pustaka Pelajar.

6. Dharmamulya, S., (2008). Permainan tradisional jawa: Sebuah upaya pelestarian, 3rd ed.

7. Eka, N., Endah, P., Mega, P., Moh, S. (2016). Nilai-nilai Karakter pada Permainan Tradisional. Prosiding Seminar Nasional Inovasi Pendidikan. Universitas Sebelas Maret. 265-273. https://jurnal.fkip.uns.ac.id/index.php/snip/article/view/8942

8. Hurlock, E.B. (1993). Perkembangan anak jilid I. Terjemahan. Jakarta: Erlangga.

9. Iswinarti (2005). Permainan Tradisional Indonesia (Dalam Tinjauan Perkembangan Intelektual, Sosial, Emosi, dan Kepribadian). Simposium Nasional: Memahami Psikologi Indonesia. Malang: Fakultas Psikologi UMM.

10. Iswinarti (2010). Nilai-Nilai Terapiutik Permainan Tradisional Engklek Pada Anak Usia Sekolah Dasar. HUMANITY, 6(1), 41 - 44.

11. Iswinarti. (2017). Niilai-Nilai Problem Solving Permainan Tradisional Engklek. Seminar Nasional Dan Gelar Produk | Senaspro 2016.2 1-9. https://www.researchgate.net/publication/320620169_Nilai nilai_Problem_Solving_Permainan_Tradisional_Engklek

12. Iswinarti. (2017). Permainan Tradisional: Prosedur dan Analisis Manfaat Psikologis. Malang: Universitas Muhammadiyah Malang. 
13. Misbach, I. (2006). Peran Permainan Tradisional Yang Bermuatan Edukatif Dalam Menyumbang Pembentukan Karakter Dan Identitas Bangsa, Tesis UPI Bandung:Tidak Diterbitkan.

14. Morrison, G. S., (2015). Pendidikan Anak Usia Dini Saat Ini. Yogyakarta: Pustaka Pelajar.

15. Papalia, D. E., Old, S. W., \& Feldman, R.D. (2000). Human Development. Boston: Mc.graw Hill.

16. Primasari, D. A. G. (2019). Prosiding Seminar Nasional Pendidikan Program Pascasarjana Universitas Pgri Palembang 12 Januari 2019. 1100-1118.

17. Santrock, J.W. (2000). Lifespan development. Boston: McGraw-Hill College.

18. Sedyawati, E. (1999). Permainan Anak-anak sebagai Aspek Budaya. Dolanan anak: Refleksi budaya dan wahana tumbuhkembang anak. Yogyakarta: Plan International IndonesiaYogyakarta dan LPM Sosiatri Fisipol UGM.

19. Seriati, N.N dan Nur Hayati. (2010). Permainan Tradisional Jawa Gerak dan Lagu Untuk Menstimulasi Keterampilan Sosial Anak Usia Dini. Lumbung Pustaka Universitas Negeri Yogyakarta. https://eprints.uny.ac.id/3835/

20. Tzeng, S. K. \& Huang, C. F (2010). A Study of the interactive "Hopscocth" game for the children using music technique. The international journal of multimedia \& its application, 2 (2), 32-34.

21. Zubaedi. (2012). Desain pendidikan karakter: konsepsi dan aplikasinya dalam lembaga pendidikan. Jakarta: Kencana.

\section{PROFIL SINGKAT}

Ni Putu Eni Astuti adalah dosen Program Studi Pendidikan Guru Sekolah Dasar, Sekolah Tinggi Keguruan dan Ilmu Pendidikan (STKIP) Suar Bangli, Bali. Ia juga merupakan praktisi yoga bagi anak usia sekolah dasar. Fokus penelitiannya adalah psikologi pendidikan dan pendidikan karakter anak usia sekolah dasar. 